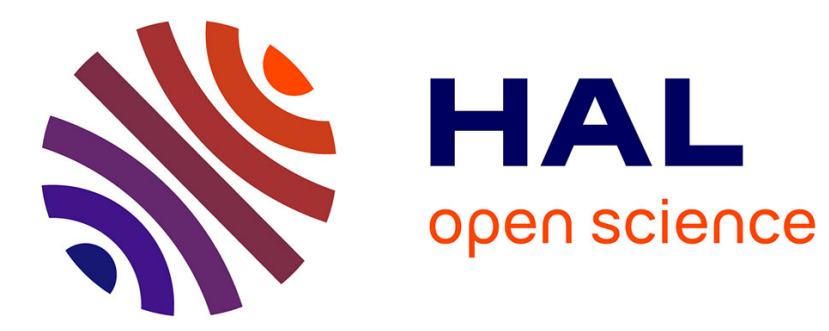

\title{
Real-time sonoporation through HeLa cells
}

Spiros Kotopoulis, Anthony Delalande, Chantal Pichon, Michiel Postema

\section{To cite this version:}

Spiros Kotopoulis, Anthony Delalande, Chantal Pichon, Michiel Postema. Real-time sonoporation through HeLa cells. AIP Conference Proceedings, 2012, NONLINEAR ACOUSTICS STATE-OFTHE-ART AND PERSPECTIVES: 19th International Symposium on Nonlinear Acoustics, 1474 (1), pp.271-274. 10.1063/1.4749348. hal-03186072v2

\section{HAL Id: hal-03186072 \\ https://hal.science/hal-03186072v2}

Submitted on 13 Apr 2021

HAL is a multi-disciplinary open access archive for the deposit and dissemination of scientific research documents, whether they are published or not. The documents may come from teaching and research institutions in France or abroad, or from public or private research centers.
L'archive ouverte pluridisciplinaire $\mathbf{H A L}$, est destinée au dépôt et à la diffusion de documents scientifiques de niveau recherche, publiés ou non, émanant des établissements d'enseignement et de recherche français ou étrangers, des laboratoires publics ou privés.

$$
\text { Copyright }
$$




\title{
Real-time sonoporation through HeLa cells
}

\author{
Spiros Kotopoulis ${ }^{*, \dagger}$, Anthony Delalande**, Chantal Pichon ${ }^{* *}$ and Michiel \\ Postema* \\ *Department of Physics and Technology, University of Bergen, Allégaten 55, 5007 Bergen, Norway \\ ${ }^{\dagger}$ National Centre for Ultrasound in Gastroenterology, Haukeland University Hospital, Bergen, \\ Norway \\ ${ }^{* *}$ Centre de Biophysique Moléculaire, UPR 4301 CNRS affiliated to the University of Orléans, rue \\ Charles Sadron, 45071 Orléans Cedex 2, France
}

\begin{abstract}
The purpose of this study was to investigate the physical mechanisms of sonoporation, to understand and ameliorate ultrasound-assisted drug and gene delivery. Sonoporation is the transient permeabilisation of a cell membrane with help of ultrasound and/or an ultrasound contrast agent, allowing for the trans-membrane delivery and cellular uptake of macromolecules between $10 \mathrm{kDa}$ and $3 \mathrm{MDa}$. We studied the behaviour of ultrasound contrast agent microbubbles near cancer cells at low acoustic amplitudes. After administering an ultrasound contrast agent, HeLa cells were subjected to $6.6-\mathrm{MHz}$ ultrasound with a mechanical index of 0.2 and observed with a highspeed camera. Microbubbles were seen to enter cells and rapidly dissolve. The quick dissolution after entering suggests that the microbubbles lose (part of) their shell whilst entering. We have demonstrated that lipid-shelled microbubbles can be forced to enter cells at a low mechanical index. Hence, if a therapeutic load is added to the bubble, ultrasound-guided delivery could be facilitated at diagnostic settings. However, these results may have implications for the safety regulations on the use of ultrasound contrast agents for diagnostic imaging.
\end{abstract}

Keywords: Sonoporation, Ultrasound, Microbubbles, HeLa Cancer cells, Drug delivery, Low Mechanical Index

PACS: $3.25 . Y w m, 43.25 . \mathrm{Nm}, 43.30 . \mathrm{Lz}, 43.35 . \mathrm{Ty}$

\section{INTRODUCTION}

In medical-diagnostics, guidelines state an $\mathrm{MI}<0.3$ can be considered safe for pregnant women and neonatals, but yet diagnostic imaging machines allow the use of MI up to 1.9. Sonoporation is the transient permeabilisation and resealing of a cell membrane with the help of ultrasound and/or an ultrasound contrast agent, allowing for the transmembrane delivery and cellular uptake of macromolecules between $10 \mathrm{kDa}$ and $3 \mathrm{MDa}$ [1]. Previous studies on non-invasive, ultrasound-induced therapeutics used acoustic amplitudes corresponding to mechanical indices between 0.2 and $7.0[2,3]$. Many studies have demonstrated increased drug and gene uptake of sites under sonication $[4,5,6]$. These studies presumed that a physical membrane disruption mechanism, i.e. sonoporation, caused the increased uptake, as opposed to naturally occurring active uptake processes, such as endocytosis, which are controlled by the system biology. Here we examin the effect of low MI ultrasound $(\mathrm{MI}=0.2)$ in combination with lipid shelled, gas filled microbubbles on HeLa cancer cells. Figure 1 shows six possible mechanisms of sonoporation. 


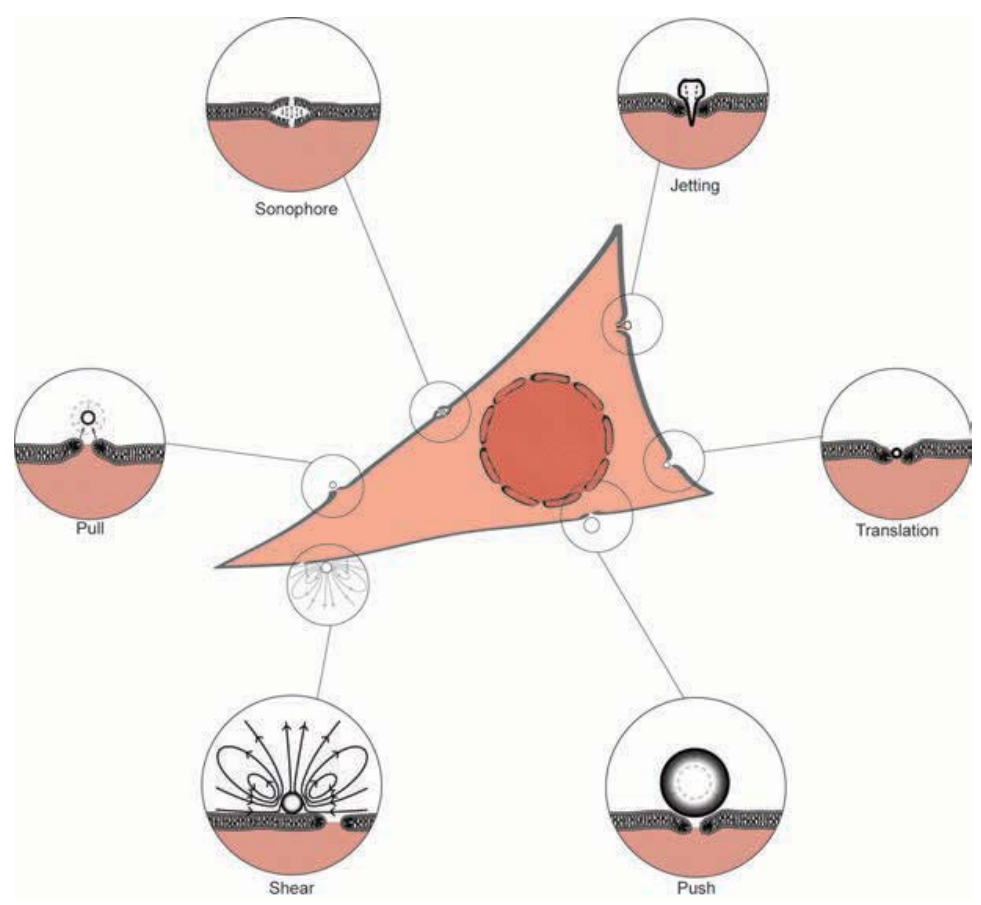

Figure 1. Possbile mechanisms of sonoporation.

\section{METHODS}

An overview of the experimental setup is shown in Figure 2. We have described our experimental setup extensively in Delalande et al. [7]. In short, a signal consisting of 40 cycles with a centre frequency of $6.6 \mathrm{MHz}$ and a pulse repetition frequency of $10 \mathrm{kHz}$, was generated by an AFG3102, dual channel arbitrary function generator (Tektronix, Inc., Beaverton, OR), amplified by a $2100 \mathrm{~L}, 50-\mathrm{dB}$ RF amplifier (Electronics \& Innovation Ltd., Rochester, NY) and fed to a custom-built 6.6-MHz ultrasound transducer. The peak-negative acoustic pressure corresponds to an MI of 0.2. The transducer was placed in a custom-built, $260 \times 160 \times 150(\mathrm{~mm})^{3}$ Perspex sonication chamber, in which an OptiCell cell culture chamber (Nunc GmbH \& Co. KG, Langenselbold, Germany) was placed. One side of the cell culture chamber contained a monolayer of HeLa cells. A customised BXFM-F microscope unit with an LCAch N 20×/0.40 NA PhC (OlympusDeutschland GmbH, Hamburg, Germany) and a LUMPlanFL $60 \times / 0.90$ NA waterimmersion objective (Olympus) was placed on top of the sonication chamber with the objective lens immersed in the water. The colour charge coupled device (CCD) of a PHOTRON FastCam MC-2.1 high-speed camera (VKT Video Kommunikation GmbH, Pfullingen, Germany) was connected to the microscope. 


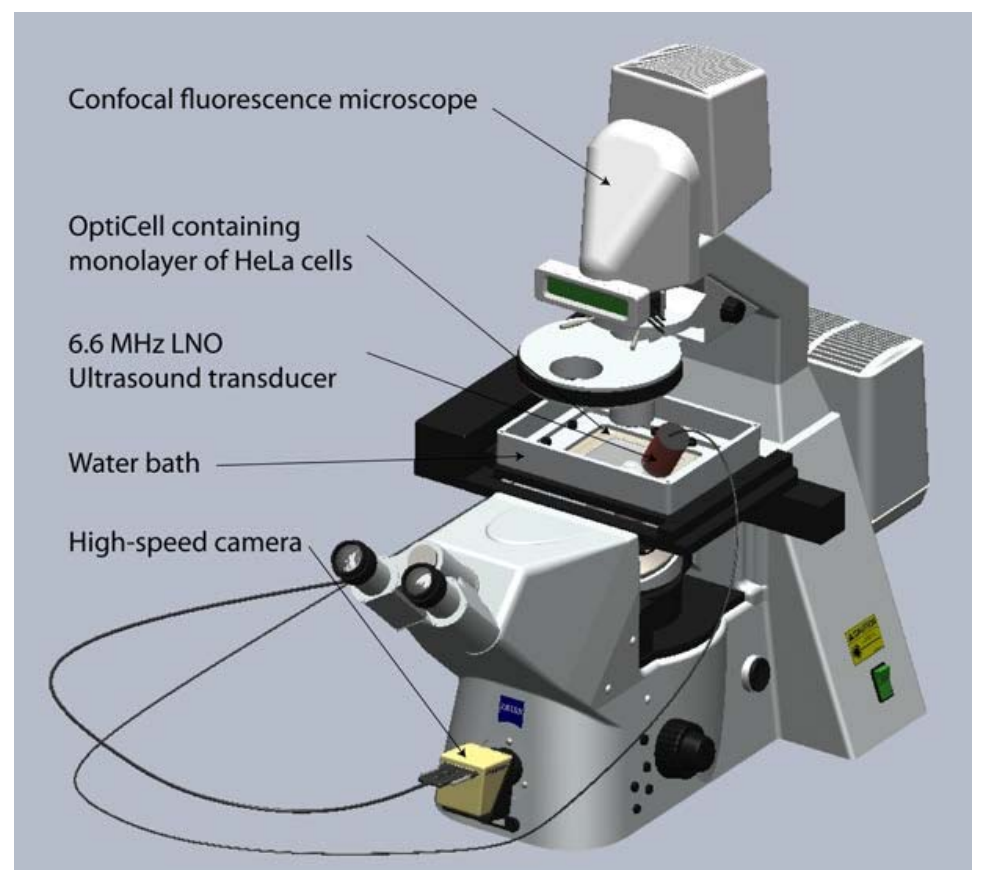

Figure 2. Confocal fluorescence configuration used to simultaniously observe and sonicate HeLa cells in the pressance of fluorescence coated microbubbles.

\section{RESULTS AND DISSCUSSION}

Lipid-shelledmicrobubbles were forced into cells using pulsed ultrasound at $\mathrm{MI}=0.2$ at transmit frequencies of $1.0 \mathrm{MHz}$ and $6.6 \mathrm{MHz}$. This phenomenon typically takes $2 \mathrm{~s}$ from the moment a bubble contacts the cell membrane, to complete dissolution of the gas inside the cell. Most bubbleâĂŞcell penetration occurred within $8 \mathrm{~s}$ from the start of sonication. These results were easily reproducible, independent of the setup geometry. We are the first to observe the translation of entire microbubbles into cells. Figure 3 shows a 3D reconstruction of the results seen. Targeted drug delivery down to the cellular level, with the use of encapsulated bubbles will allow the use of high-toxicity drugs to be injected into the body, but only delivered to a specific area. Thus, leaving healthy tissue unaffected. Our sonoporation observations could be attributed to the long pulse lengths used. Although cells themselves are acoustically active, this acoustic activity is probably negligible to that of microbubbles in high concentrations. Therefore, we expect bubble-cell interaction to be more likely in very low bubble concentrations.

\section{CONCLUSION}

It has been demonstrated that lipid-shelled microbubbles can be forced to enter cells at a low MI. Hence, if a therapeutic load is added to the bubble, ultrasound guided delivery could be facilitated at diagnostic settings. In addition, these results may have 


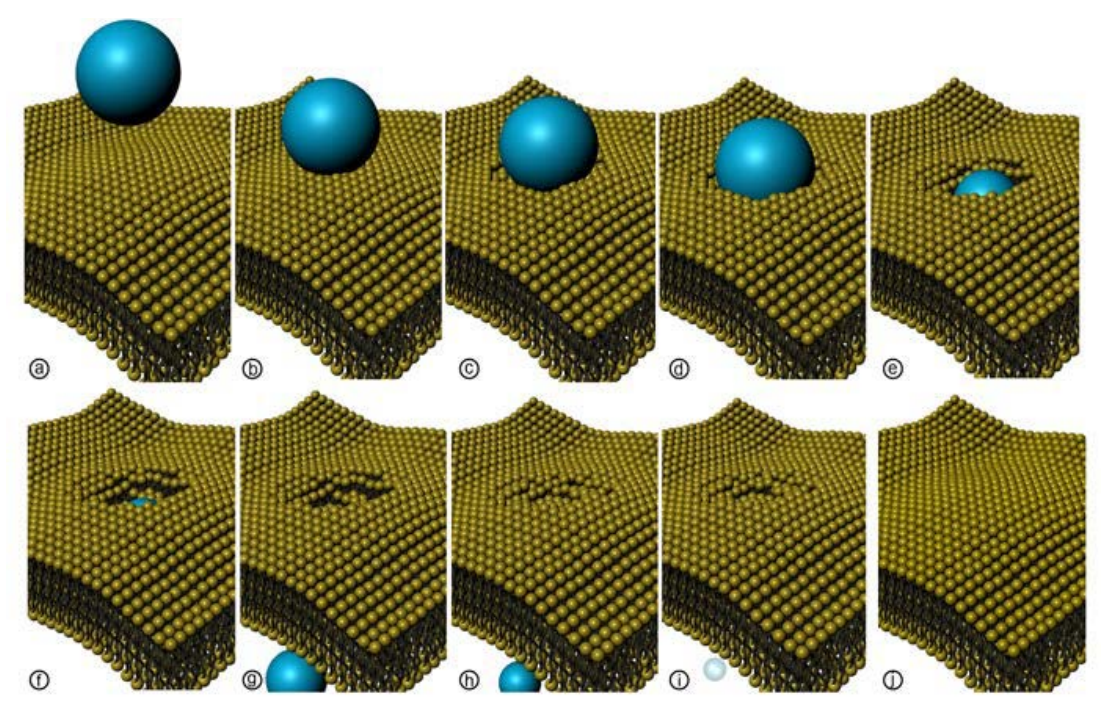

Figure 3. 3D reconstruction of microbubble translation through a cell membrane. Once the microbubble has translated through the membrane, the pore re-seals and the microbubble is seen to disolve.

implications for the safety regulations on the use of ultrasound contrast agents for diagnostic imaging.

\section{ACKNOWLEDGMENTS}

This work has been supported by DFG Emmy Noether Programme (grant no. 38355133) and Engineering and Physical Sciences Research Council (EPSRC) (grant no. EP/F037025/1).

\section{REFERENCES}

1. M. Postema and O. H. Gilja. Ultrasound-directed drug delivery. Curr. Pharm. Biotechnol., 8(6):355361, 2007.

2. C. X. Deng, S. Pan, and J. Cui. Ultrasound-induced cell membrane porosity. Ultrasound Med. Biol., 30:519-526, 2004.

3. E. Pua and P. Zhong. Ultrasound-mediated drug delivery. IEEE Eng. Med. Biol., 28(1):64-75, 2009.

4. I. Kondo, K. Ohmori, A. Oshita, H. Takeuchi, S. Fuke, K. Shinomiya, T. Noma, T. Namba, and M. Kohno. Treatment of acute myocardial infarction by hepatocyte growth factor gene transfer: the first demonstration of myocardial transfer of a "functional" gene using ultrasonic microbubble destruction. J. Am. Coll. Cardiol., 44(3):644-653, 2004.

5. N. Kudo, K. Okada, and K. Yamamoto. Sonoporation by single-shot pulsed ultrasound with microbubbles adjacent to cells. Biophys. J., 96(12):4866-4876, 2009.

6. J. R. Lindner and S. Kaul. Delivery of drugs with ultrasound. Echocardiography, 18(4):329-337, 2001.

7. A. Delalande, S. Kotopoulis, T. Rovers, C. Pichon, and M. Postema. Sonoporation at a low mechanical index. Bub. Sci. Eng. Tech., 3(1):3-11, 2011. 